\title{
An Insight of Ecosystem Capitals and Services of the Kaghan Valley: The Himalayan Region of Pakistan
}

\author{
Muhammad Qasim¹, Muhammad Zafarullah Khan ${ }^{2}$, Alia Naz ${ }^{1}$, Salma Khalid ${ }^{1}$ \\ ${ }^{1}$ Department of Environmental Sciences, Abdul Wali Khan University, Mardan, Pakistan; ${ }^{2}$ Department of Agriculture Extension and \\ Communication, Agricultural University, Peshawar, Pakistan. \\ Email: drqasim@awkum.edu.pk
}

Received December $5^{\text {th }}, 2012$; revised March 14 ${ }^{\text {th }}, 2013$; accepted April 6 ${ }^{\text {th }}, 2013$

Copyright (c) 2013 Muhammad Qasim et al. This is an open access article distributed under the Creative Commons Attribution License, which permits unrestricted use, distribution, and reproduction in any medium, provided the original work is properly cited.

\begin{abstract}
The Kaghan Valley is in the territorial jurisdiction of Mansehera District, named after a tiny village Kaghan, at the end of the valley. The valley culminates in the tree-clad high mountains and glaciers in the North-East with varying altitudes from 1 to 5 thousand meters above sea level. The region is relatively active geophysically, hydrologically and biologically diverse by virtue of the altitude and aspect-driven variability in energy and moisture. In such region a better understanding of changes in land resources, production of agronomic and horticultural crops, use of timber and non-timber products, and livestock structure/composition have important implications and understanding these changes along with the indigenous knowledge of mountain people which, is key to sustainable development of the Himalayan region. Our results showed that the main causes of lowest agriculture production in the area are poor crop management in context of the mountains, drought spells, low soil fertility, land fragmentation and tenancy status of the agricultural land. Off season vegetables cultivation on the sloppy land leads to sever soil erosion and soil land degradation of this mountain ecosystem. Overgrazing during the summer season is another problem as the pastures are visited both by the Afghan and local nomads without relating with carrying capacity of the alpine meadows. The overgrazed soil is usually subject to rainfalls and severe soil erosion. Any use of resources of such fragile rare high mountain ecosystem requires a great sense of responsibility but in this case the forest resources are being plundered and are used roughly. We recommend adequate use of agricultural inputs, specific crop management practices for mountain agriculture. Local social welfare organizations should work to create awareness about the sustainable use of natural resources. The government should resolve the ownership problem of land as common property keeping in mind the customary laws of the region to make sure the involvement of all stakeholders.
\end{abstract}

Keywords: Natural Resources Management; Mountain Agriculture; Livelihood Analysis; Kaghan Valley; Pakistan

\section{Introduction}

The Mountain areas cover one fifth of the earth's surface. Mountain ecosystems are crucial to many countries, because of water resources and also because they contain a large share of the world's biological diversity. Fully half of the world's people depend on mountain watersheds for fresh water [1-3]. The Kaghan Valley of Pakistan is composed of the high altitudinal mountains of the Himalayan region. The great Himalayas are the largest mountain system in the world with uncounted and unique wild resources. Hima- layas of this region has its own climatic system and piedmont habitats that have given rise to considerable biological diversity in ecosystems, species and genetic resources [4-6]. The interaction between the mountain people and nature through history has helped in maintaining the richness of species, communities and genetic materials in both productive way and as wild flora and fauna of the mountain environment [6,7]. Different people have been using new approaches for reducing poverty among mountain communities and these approaches are mainly aimed at improving their livelihoods through sustainable natural resources management [7-10]. Agriculture is the main sector which is heavily dependent on the quality and utilizing patterns of natural resources for higher productivity in this part of the world and thus optimum utilization of the scarce natural resources for more productive purposes is very important $[3,11,12]$. Unfortunately, these natural resources (land, water, timber and non-timber forest products and range- 
land) were exploited without any consideration about their regeneration, conservation and rehabilitation [1316]. Above all the more serious dimension of this issue is that the farmers of the area are not realizing the severity of the issue in its true sense, while the public and private sector organization working for the rehabilitation, regeneration, protection and conservation are less effective and quite minimal in amount. Understanding the indigenous knowledge of mountain people in relation to biodiversity resource management is one of the key issues for sustainable development of the Himalayan region today [17]. Changes have been taking place over the years with respect to cropland use, timber and non-timber products from forest, production of agronomic and horticultural crops and livestock structure and composition. It is necessary that the farmers who are real custodians of these natural resources should be trained and informed about sustainable management of these natural resources, because they will be affected of the consequences in the long run. A better understanding of the changes in ecocapitals and ecosystem services can have important implications for development of sustainable mountain agriculture. Understanding the knowledge of mountain people, their participation in natural resources management is one of the key issues for sustainable development of the Himalayan region today. The present paper looks into the details of current ecosystem services and the deteriorating situation of natural resources with possible solutions.

\section{Methods}

\subsection{Study Area}

The valley is in the jurisdiction of district Mansehera, named after a tiny village Kaghan, which is positioned just next to Kunhar river at the latitude of $34^{\circ} 78^{\prime} \mathrm{N}$ and longitude of $73^{\circ} 57^{\prime} \mathrm{E}$ (see Figure 1). The elevation of Kaghan village is about 2040 meter above sea level.

Mansehera, Naran Jalkad (MNJ) Road is the only access to the valley, which has recently widened and expanded. The nearest town to the valley is "Balakot" while other important villages of the valley are Kawai, Paras, Mahandri, Kaghan and Naran. The area possesses different topography, having mostly hilly tracts and very few planes. Rainfall occurs in the monsoon and winter, the average being $2500 \mathrm{~mm}$ per year. Snowfall starts by the end of November and continues till the end of February, which may stay on mountains for several weeks. The winter is severe with heavy snowfall which is expected any time from mid-December onward. The highest maximum and lowest minimum temperature recorded are $30.5^{\circ} \mathrm{C}$ in June and $-6.0^{\circ} \mathrm{C}$ in January.

The valley is surrounded by roughly parallel ranges which rise to $5291 \mathrm{~m}$ at Malika Parbat; it is drained by

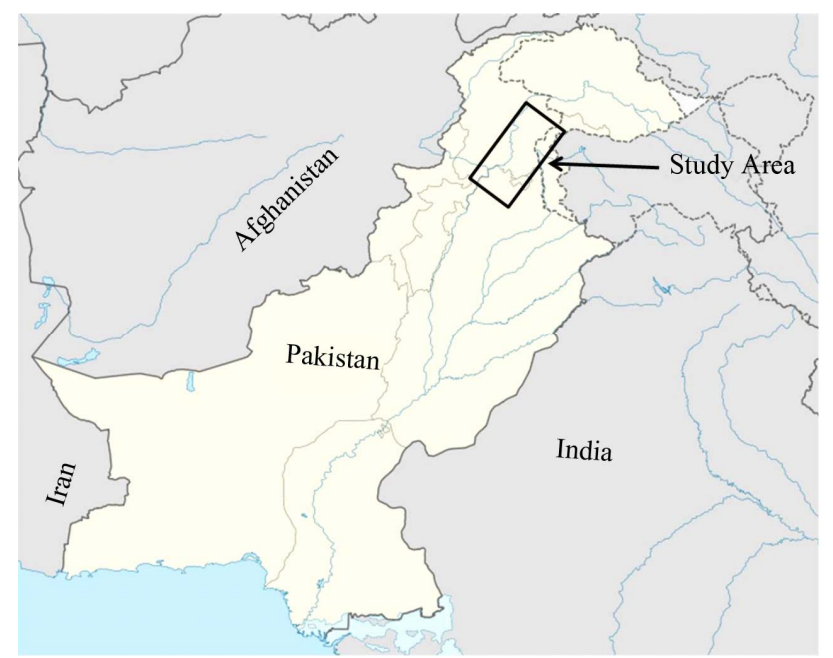

Figure 1. Study Area on Map of Pakistan.

the Kunhar River, which flows from Lulusar Lake to the Jhelum. The valley is about $96 \mathrm{~km}$ long and hardly 24 $\mathrm{km}$ wide, covering $945 \mathrm{~km}^{2}$. Major land uses are grazing $55 \%$, forest $24.6 \%$, agriculture $2.6 \%$ and the rest is built up, roads or barren land. Every available piece of land is cultivated, from terraces built with great labour on hillsides, to rich irrigated valley bottoms. Maize is grown as major crop, wheat and rice is also grown in pockets. Potato is replaced by off season vegetables in most of the areas however fruits are less common. The most commercially grown important fruits are apple, walnut, plum, pear and apricot. Almost all the valley is subject to grazing of varying intensity and frequency.

\subsection{Data Collection and Analysis}

House hold survey and expert interviews were conducted to collect data from five villages of the valley. Villages were selected to make sure the representation of each sub ecological zone and respondents from each ethnic group of the valley. A questionnaire with closed and openended questions was used to collect information about age, education, income sources, crop management, agricultural inputs and method of application, land holding, use of timber and non-timber products, number of livestock, mode of feeding/grazing, and involvement in grazing land management.

Different expert including government officials, local leaders, subject specialists and experts from NGOs were interviewed to get info about local history, changes in socio-economic conditions that were related to mountain agriculture, natural resources management, land use change, indigenous resource division etc. The number of experts interviewed was based on theoretical saturation of the information gathered.

Considering the nature of quantitative data mainly des- 
criptive statistics were used for analysis, while qualitative data from expert interviews, household surveys was analyzed through content analysis and were developed into categories, themes and subsections to support other data.

\section{Results and Discussion}

\subsection{Agriculture and Its Related Issues in the Valley}

Kaghan and the northern part of the Kunhar valley is a mono-cropping zone. Major crops of the area are Maize, Potato, and Beans. The people of Kaghan valley have evolved its particular system of agriculture based on its agro biodiversity, topographic and climatic conditions, the predominance of the tribal traditions, and reliance on seasonal transhumant animal husbandry. Less education, small agric land holding, water and other agric input availability, tenancy status, off season vegetables production and in appropriate agricultural practices, sloppy and less fertile land are the major issues and thus the local farmers could not managed to keep a reasonably productive system as the following detailed results shows.

\subsection{Education}

Education plays primary role in adoption of new technologies and improved techniques for higher agricultural production. Among the surveyed farmers of Kaghan valley the education ratio was quite lower. $71 \%$ of the respondents were illiterate, $24 \%$ were matriculate, $4 \%$ were educated up to FA and only $1 \%$ were graduates or post graduate. This comparatively low level of education may be because of poor socio economic conditions of the growers and less educational facilities in the valley. Reference [18] worked on the role of education in agriculture. He used a dichotomous probit and a two-limit tobit model and his results showed that education has a positive impact on the adoption of new agricultural technologies.

\subsection{Small Landholdings and Cultivation on Sloppy Lands}

In mountains arable land is usually very scares and even available land is mostly sloppy and less fertile. Kaghan valley is no exception in this regard. Based on the data collected, there was no single respondent having one acre of agricultural land as a single piece. Majority (88\%) respondents were having a total agricultural land less than 1 acre. As agriculture is the main source of income, so they heavily depend on these small land holdings, and trying their best to maximize their income. Thus the farmers do not leave any space without cultivation ire- spective of its suitability for agriculture production.

Land is the most fundamental among natural resources on which human existence and prosperity depends in the Himalayan context $[19,20]$. The total area of Pakistan is 79.6 million hectares, of which $70 \%$ is arid to semi-arid. About 50.9 million ha (or 63.9\%) are rangelands and only 22 million ha (or 27.6\%) are cultivated lands. As the ecologies of Khyber Pakhtunkhwa and Northern Areas range from semi-arid to humid [21,22], therefore the present use of land as a whole is not quite in accordance with its potential. Rather it is based on opportunity, economic status and the socioeconomic needs of the user. While much of the land on steep mountainous slopes suitable for forestry and rangelands are now used for food crops. Poor use of resources is emphasized when efforts are made to bring marginal or non-agricultural lands under arable use.

Soil erosion by water in the valley is one of the severe problems and its major causes are destruction of natural vegetation cover and other agricultural practices [20]. It has significantly affected agricultural production, continued deterioration of rangelands and forest reserves and their productivity for livestock farming, fuel wood and timber production as well [23].

\subsection{Agricultural Land Ownership/Tenancy Status}

Among respondent 35\% were owners while rests of the growers were tenants, having agricultural land on lease for as long as for 5 to 15 years or even more. This had bad effect on land management, as most of the agricultural fields were found in bad condition and agricultural production was far less than its potential. One of the key reasons for such a result is the lack of security which inhibits any long-term investments on farm by farmers operating on leased land. This is an example of how markets fail to allocate resources efficiently when some of the prerequisites for the market to function efficiently are not fulfilled.

The problem of lack of ill-defined property rights is not only a hindrance to increased efficiency and productivity in the agriculture sector, but also to other sectors of the economy where it depresses investor confidence. Well defined property rights, which require markets to function properly, should have the characteristics of universality, exclusivity, transferability and enforceability [24-26].

\subsection{Water Resources for Irrigation and Other Uses}

Two major irrigation sources identified in the valley were snow melt and spring water apart from rain fed areas. The percentages of farmers utilizing these re- 
sources were $47 \%$, $23 \%$ and $30 \%$ respectively.

The farmers informed that variability in rainfall pattern has affected their total production tremendously. According to Syed Asghar Shah of Mohandri, "in the past couple of years it's raining too much when it's not required for the crop and then not at all when crops need a lot of water" (personal communication). It is also important to be noted that there is no any proper mechanism anywhere in the valley for water harvesting. Locals depend on natural water flow as it is.

Water has extremely important role in our economy. Pakistan agriculture is also heavily dependent on water availability. At present, Pakistan is one of the world's most arid countries, with an average annual rainfall of below $240 \mathrm{~mm}$. The population and the economy of the country are heavily dependent on annual influx of about 180 billion cubic meters of water into the Indus river system of 5 rivers, mostly derived from snow melt in the Himalayas. About $88 \%$ of available water is used in agriculture. According to one estimate about $29 \%$ of total area suitable for agriculture can become productive if water is made available for irrigation [27]. Now Pakistan is one of the most water stressed countries of the world in terms of balance between population and available water [28].

\subsection{Agricultural Inputs and Practices}

Using improved crop varieties play an important role in agricultural production. As they are disease resistant, drought resistant and give more yield too. Our data showed that only $29 \%$ of respondents were using hybrid varieties of maize and pea. Another 12\% farmers were using improved verities of potatoes as well. The rest (majority) are still using traditional seed/genetic sources for major crops.

In the whole valley there is no simple example of an agricultural field where farmers have used the recommended plant to plant and row to row distance. The farmers are sowing crops either by broad cost (e.g., maize) or by planting hip hazard (e.g., potatoes and pea) without any proper spacing or lining. Keeping in view the low fertility of the soils in the valley, more number of plants per unit area further increases the competition for nutrients.

Adequate and in time fertilizer application is crucial and important for optimum crop production. Our study reviled that chemical fertilizer application is almost negligible (21\%) however majority $(60 \%)$ of the formers apply a reduced doze of organic fertilizer (Farm Yard Manure). The method of fertilizer application is broad casting at the time of sowing (77\%) or first irrigation (33\%). The fertilizer is not applied where the feeding roots are, and thus the less amount of fertilizer applied is wasted too. Kaghan valley is a mono cropping area i.e., people get one crop per year. So far farmers were depending on biological control or other indigenous methods for controlling the rare attack of insects and diseases. However household survey showed that this trend is changing slowly and gradually because now there are more insects and diseases attack, the farmers informed. In the valley (28\%) farmers are now depending on chemical pesticides especially for potatoes and other off season vegetables like pea.

\subsection{Off Season Vegetables Production}

The survey results showed that $80 \%$ farmers were producing off-season vegetable in different parts of the valley. To utilize the unique climate of the area, off-season vegetable production was introduced. In terms of improving the socio-economic conditions of the people it was a great success. The farmers were selling vegetables in the down country markets at higher prices than the normal season price. Thus not only the farm income increased but also new jobs were created. Fresh vegetables/food availability is now more secure, and an increase in marketing of agricultural inputs has positively affected the local economy.

Initially, it was a revolution for the local farmers but the situation became more complicated when people, mostly from other parts of the country, started growing off-season vegetables on a large commercial scale. These people migrate to the uplands during the summer and lease land for vegetable production. They started intensive agricultural practices without consideration of the long term effects on land degradation in the area. Massive deforestation, land erosion, biodiversity depletion, introduction of new insect pests to the area and decrease in the water retaining capacity of the soil has been linked to this rapid intensification of agriculture and partly to population increase in the Hindu Kush Himalayas (Semwal, et al., 2004)

\subsection{Medicinal Plants and Its Use}

All the respondents (100\%) were found using different medicinal plants for different diseases. Earlier it was reported that $84 \%$ of Pakistani population is dependent on traditional medicines for their medicinal needs [29]. Himalayan Mountains are rich in forest flora. The natives of Himalayas have knowledge about medicinal use of the local flora. In early 90's, 584 plant species were reported from this valley $[30,31]$. However Saeed Swati, a respondent from the valley said that "presently medicinal plants are over harvested and regeneration of most of the medicinal plants is almost negligible" (personal communication). 


\subsection{Wood Extraction}

Fuel Wood: Firewood from the natural forest is the only source of energy for cooking and heating in the study area. Due to harsh weather conditions $49 \%$ of the households use up to 20 tons of firewood and another $45 \%$ of household burn up to 30 tons of firewood annually, while in "zone C" $88 \%$ of household consume less than 10 tons firewood.

Timber extraction: Very little forest is left in the valley most of which, is categorized as protected forests and locals are not allowed to use this forest for timber extraction. But interviews with experts and households revealed that many trees are cut down illegally both for timber and firewood. Proximity of these forests to urban centre and densely populated areas makes them more vulnerable and the 'timber mafia' is comparatively more active, according to the expert interviews.

The energy for cooking and heating is traditionally obtained from firewood, for which they prune or cut down the whole tree. This is one of the contributing factors to the loss of the plant cover, which caused flooding and the loss of wildlife in the valley as well. Our findings are in line with Singh and Sundriyal (2009), who stated that in villages of central Himalayas the fuel consumption is 418.86 MT and the annual fuel availability is 211.03 MT, so there is a deficit of 207.83 MT. Limiting the excessive wood extracting activities was one of the major components in the conservation models proposed by a number of authors [such as 32-34].

\subsection{Livestock Population and Feed Problems}

Data showed that the cattle population has significantly increased compared to the past. Uncontrolled grazing particularly in upper parts of the valley where, cattle population is highest, livestock eat regenerating seedlings and reduce chances of natural regeneration of forest because of open grazing (cattle are free to graze anywhere in winter), decrease in fodder crops (as farmers preferred to cultivate vegetables) coupled with decrease in grasses (from forests due to less forest cover). As in the valley livestock eat regenerating seedlings through browsing and trampling, therefore it reduce the chances of natural forest regeneration. Land degradation and land use changes caused by over grazing and livestock population is a widespread trend in the Himalayas [35-37].

\subsection{Transhumant Migration for Maximum Utilization of Sun Energy}

Environmental management in this region is dependent on the life style of the rural communities. Most villages in Kunhar valley have a vertical migratory pattern to alpine pastures, where they spend a third of the year. The adjacent alpine pastures to the area have its own names, and acts like a second home with its own production habitat and farming system. These adjacent rangelands/ alpine pastures are kept and managed as common property.

Reference [38] described transhumant migration as an, "extreme case of a human society's adaptation to a unfriendly natural environment". Other studies highlighted the problems of balance between availability of natural resources (water and fodder), livestock number and population size [39,40]; common land use and its regulation [41]; changing environmental conditions, particularly due to environmental degradation resulting from development and pastoralists response to droughts etc. It has been shown that pastoral nomads diversify their resources in order to survive in harsh and unpredictable weather conditions.

\subsection{Institutional Support}

During expert interviews it was reviled that many institutions both at federal, provincial and local levels are involved in carrying out research and development activities for the controlling deforestation and conservation of natural resources. All institutions are working primarily for the betterment of their respective geographical areas and welfare of the farmers. No doubt, the objectives/ functions of these institutions are appreciable in their own place, but unfortunately they are very less in number and quite in active as well which, signifies the lack of co-ordination, implementation and dissemination of information to the local communities. On the other hand, local population is hardly aware of their activities it is evident from the negligible adoption of most of the technological developments made so far. This has been observed in the Hindu Kush Himalayan region [15]. Many such examples may be available for other agriculturally less developed areas also.

\section{Conclusion and Recommendations}

This study was conducted in Kaghan Valley, which is part of Mansehera District in northern Pakistan. The study is based on household survey and expert interviews. Kaghan valley culminates in the tree-clad high mountains and glaciers in the North-East with varying altitudes from 1 to 5 thousand meters above sea level. The region is relatively active geophysically, hydrologically and biologically diverse by virtue of the altitude and aspectdriven variability in energy and moisture. Agriculture in this region is now treated a bit differently as it is the only sector which entirely depends on the quality of natural resources for sustaining higher productivity.

Our results showed that main causes of lowest agriculture production in the area are poor crop management 
in context of the mountains, drought spells, low soil fertility, land fragmentation and tenancy status of the agricultural land. Off season vegetables cultivation on the sloppy land leads to severe soil erosion and soil land degradation of this mountain ecosystem. Overgrazing is another problem as the pastures are visited both by the local and non-local nomads without relating with carrying capacity of the alpine meadows. The overgrazed soil is usually subject to rainfalls and severe soil erosion. Any use of natural resources of such fragile rare high mountain ecosystem requires a great sense of responsibility but in this case the forest resources are being plundered and are used roughly.

We recommend adequate use of agricultural inputs, specific crop management practices for mountain agriculture. Local social welfare organizations should work to create awareness about the sustainable use of natural resources. The government should resolve the ownership problem of land as common property keeping in mind the customary laws of the region to make sure the involvement of all stakeholders.

\section{REFERENCES}

[1] D. Denniston, "High Priorities: Conserving Mountain Ecosystem and Cultures,” Reference: Worldwatch Paper 123, Worldwatch Institute, Washington DC, 1995.

[2] P. H. Gleick, "Water and Conflict," International Security, Vol. 18, No. 1, 1993, pp. 79-112. doi:10.2307/2539033

[3] A. Wakeel, K. S. Rao, R. K. Maikhuri and K. G. Saxena "Forest Management and land Use/Cover Changes in a Typical Micro Watershed in the Mid Elevation Zone of Central Himalaya, India,” Forest Ecology and Management, Vol. 213, No. 1-3, 2005, pp. 229-242. doi:10.1016/j.foreco.2005.03.061

[4] T. Ali, B. Shabaz and A. Suleri, "Analysis of Myths and Realities of Deforestation in Northerwest Pakistan: Implications for Forestry Extension,” International Journal of Agriculture \& Bilology, Vol. 8, No. 1, 2006, pp. 107110.

[5] ICIMOD, "Poverty and Social Exclusion in the South Asian Highlands State of the Social Sector and Opportunities for Poverty Reduction and Social Inclusion,” Issues in Mountain Development No. 1. (International Centre for Integrated Mountains Development, Kathmandu, 2000.

[6] J. Khan, “Constraints and Opportunities for Sustainable Livelihoods and Forest Management in the Mountains of the North-West Frontier Province, Pakistan,” Faculty of Life Sciences, The University of Reading, Reading, 2004.

[7] R. S. Khan, M. Yusuf and I. U. Haq, "Assessing the PovertyEnvironment Nexus: Evidence from Swat,” Poverty Reduction Environmental Management Programme (PREM), Amsterdam, 2006.

[8] N. S. Jodha, "Natural Resource Management and Poverty Alleviation in Mountain Areas: Approaches and Efforts," Conference Paper Series No. 11, International Conference on Natural Assets, Tagaytay City, 8-11 January
2003, pp. 89-104.

[9] Z. Ali, A. M. Haqqanni and M. Ahmad, "Thal and Technologies for Fodder Production,” Science, Technology and Development, Vol. 24, No. 3, 2005, pp. 87-95.

[10] A. M. Haqqanni, Z. Ali, S. Shafique, S. Zahid and A. Bakhsh, "Oats: A Fodder of Winter Lean Period," AgriDigest Journal of Zari Taraqiati Bank Limited, 2003, pp. 15-23.

[11] P. M. Tulakchan, "Mountain Agriculture in the Hindu Kush-Himalaya,” Mountain Research and Development, Vol. 21, No. 3, 2001, pp. 260-267. doi:10.1659/0276-4741(2001)021[0260:MAITHK]2.0.C $\mathrm{O} ; 2$

[12] B. Shabaz and T. Ali, "Participatory Forest Management: Analysis of Forest Use Patterns, Livelihood Strategies and Extent of Participation of Forest Users in Mansehra and Swat districts of Pakistan," In: Shabaz et al., Eds., Troubled Times: Sustainable Development and Governance in the Age of Extremes, Sustainable Development Policy Institute, City Press, Islamabad, 2006, pp. 148158.

[13] N. S. Jodha, "Poverty and Environmental Resource Degradation: An Alternative Explanation and Possible Solutions,” In: N. S. Jodha, Ed., Life on the Edge: Managing Agriculture and Community Resources in Fragile Environments, Oxford University Press, Delhi, 2001, pp. 113130.

[14] FAO, “Global Forest Resources Assessment 2005,” Progress towards Sustainable Forest Management, 2005, p. 320.

[15] K. S. Bawa, G. Joseph and S. Setty, "Poverty, Biodiversity and Institutions in Forest-Agriculture Ecotones in the Western Ghats and Eastern Himalaya Ranges of India," Agriculture, Ecosystems \& Environment, Vol. 121, No. 3, 2007, pp. 287-295. doi:10.1016/j.agee.2006.12.023

[16] P. Tiwari, "Land Use Changes in Himalaya and Their Impacts on Environment, Society and Economy: A Study of the Lake Region in Kumaon Himalaya, India,” Advances in Atmospheric Sciences, Vol. 25, No. 6, 2008, pp. 1029-1042. doi:10.1007/s00376-008-1029-X

[17] S. J. Pei, “Indigenous Knowledge of the Mountain People and Conservation of Biodiversity in the Mountain Ecosystems,” ICIMOD, Nepal, 1994.

[18] J. Y. Lin, "Education and Innovation Adoption in Agriculture: Evidence from Hybrid Rice in China,” American Journal of Agriculture Economics, Vol. 73, No. 3, 1991, pp. 713-723. doi:10.2307/1242823

[19] AP Gautam, EL Webb, GP Shivakoti and MA Zoebisch, "Land Use Dynamics and Landscape Change Pattern in a Mountain Watershed in Nepal,” Agriculture, Ecosystems \& Environment, Vol. 99, No. 1-3, 2003, pp. 83-96. doi:10.1016/S0167-8809(03)00148-8

[20] M. Qasim, K. Hubacek, M. Termansen and A. Khan, "Spatial and Temporal Dynamics of Land Use Pattern in District Swat, Hindu Kush Himalayan Region of Pakistan,” Applied Geography, Vol. 31, No. 2, 2011, pp. 820828. doi:10.1016/j.apgeog.2010.08.008

[21] PCRWR, "Pakistan Council of Research in Water Resources, Regional Office, Bahawalpur,” Information Book- 
let, 1999.

[22] M. Iqbal, U. Farooq, A. Bashir, N. A. Khan and S. Z. Malik, "A Baseline Survey for the Development of Livestock Sector in Cholistan," Joint Publication of AERU, AARI, Faisalabad, SSI, NARC, Islamabad and GTZ, Lahore, 2000.

[23] A. Mian, and M. Y. J. Mirza, "Pakistan’s Soil Resources,” Pakistan's National Conservation Strategy Paper No. 4, Jointly Published by IUCN Pakistan and Environment \& Urban Affairs Division, Government of Pakistan, 1993.

[24] R. A. Posner, “Economic Analysis of Law,” Little Brown, Boston, 1972.

[25] A. Randall, "Resource Economics,” John Wiley and Son, New York, 1987.

[26] T. H. Tietenberg, "Environmental and Natural Resource Economics,” Harper Collins Publishers Inc., New York, 1992.

[27] PILDAT (Pakistan Institute of Legislative Development and Transparency), "Issues of Water Resources in Pakistan,” PILDAT Brief Paper No. 7, Pakistan Institute of Legislative Development and Transparency, 2003. www.pildat.org

[28] World Bank, "World Development Report 2008: Agriculture for Development," World Bank, Washington DC, 2007.

[29] G. M. Hocking, "Pakistan Medicinal Plants I,” In: Qualitas Plantarum et. Material Vegetabiles, Vol. 5, 1958, pp. 145-153.

[30] M. K. Kaul, V. Singh, P. K. Sharma and A. K. Bhatia, "Ethnobotanic Studies in Northwest and Trans-Himalaya, II. Approaches to the Study of Ethnobotany towards the Human Welfare in Remote Northwest and Trans-Himalayas," Journal of Economic and Taxonomic Botany, Vol. 14, No. 2, 1990, pp. 271-286.

[31] A. A. Khan, "Propagation and Regeneration Technology of Pharmacopoeial Medicinal Plants of Temperate Regions of Pakistan,” Pakistan Forest Institute, Peshawar, 1989.

[32] M. Boissière, D. Sheil, I. Basuki, M. Wan and H. Le, "Can Engaging Local People's Interests Reduce Forest Degradation in Central Vietnam?” Biodiversity and Con- servation, Vol. 18, No. 10, 2009, pp. 2743-2757. doi:10.1007/s10531-009-9627-1

[33] P. L. Sankhayan, N. Gurung, B. K. Sitaula and O. Hofstad, "Bio-Economic Modeling of Land Use and Forest Degradation at Watershed Level in Nepal,” Agriculture, Ecosystems \& Environment, Vol. 94, No. 1, 2003, pp. 105116. doi:10.1016/S0167-8809(02)00009-9

[34] S. Wunder, "Poverty Alleviation and Tropical ForestsWhat Scope for Synergies?” World Development, Vol. 29, No. 11, 2001, pp. 1817-1833. doi:10.1016/S0305-750X(01)00070-5

[35] R. K. Maikhuri, S. Nautiyal, K. S. Rao, K. Chandrasekhar, R. Gavali and K. G. Saxena, "Analysis and Resolution of Protected Areas-People Conflicts in Nanda Devi Biosphere Reserve, India,” Environmental Conservation, Vol. 27, No. 1, 2000, pp. 43-53. doi:10.1017/S0376892900000060

[36] G. Krishan, S. Kushwaha and A. Velmurugan, "Land Degradation Mapping in the Upper Catchment of River Tons," Journal of the Indian Society of Remote Sensing, Vol. 37, No. 1, pp. 119-128. doi:10.1007/s12524-009-0003-0

[37] J. S. Perkins and D. S. G. Thomas, "Spreading Deserts or Spatially Confined Environmental Impacts? Land Degradation and Cattle Ranching in the Kalahari Desert of Botswana," Land Degradation \& Development, Vol. 4, No. 3, 1993, pp. 179-194. doi:10.1002/ldr.3400040307

[38] L. Krader, “The Ecology of Nomadic Pastoralism,” International Social Science Journal, Vol. 11, No. 4, 1959, pp. 499-500

[39] L. E. Sweet, "Camel Pastoralism in North Arabia and the Minimal Camping Unit,” In: A Leeds and A. P. Vayda, Eds., Man, Culture and Animals: The Role of Animals in Human Ecological Adjustments, American Association for the Advancements of Science, Washington DC, 1965, pp. 121-129.

[40] W. W. Swidler, “Adaptive Processes Regulating NomadSedentary Interaction in,” University of California Press, 1973.

[41] D. W. Brombley, "Making the Common Work: Theory, Practice and Policy,” Institute for Contemporary Studies, San Francisco, 1992. 